\title{
Antimicrobial activities of fungus comb extracts isolated from Indomalayan termite (Macrotermes gilvus Hagen) mound
}

\author{
Lucia Dhiantika Witasari ${ }^{1 *}$ (D, Khairunnasa Wizdjanul Wahyu' ${ }^{1}$, Bonifasia Junita Anugrahani ${ }^{1}$, \\ Dina Clarissa Kurniawan ${ }^{1}$, Aris Haryanto², Dodi Nandika³, Lina Karlinasari³ , Arinana Arinana 3 , \\ Irmanida Batubara ${ }^{4}$, Djoko Santoso ${ }^{5}$, Yanti Rachmayanti ${ }^{6}$, Dikhi Firmansyah ${ }^{6}$, I Ketut Sudiana ${ }^{5}$ and \\ Decsa Medika Hertanto ${ }^{5}$
}

\begin{abstract}
Incorporating antimicrobial components into food packaging materials can prevent microbial contamination. Fungus combs could be an alternative source of natural antimicrobial agents. In this study, $n$-hexane, ethyl acetate, methanol, and water extracts were obtained from fungus combs isolated from Indomalayan termite (Macrotermes gilvus Hagen) mound. Their antibacterial and antifungal activities against food spoilage microorganisms including Escherichia coli ATCC 25922, Pseudomonas aeruginosa ATCC 27853, Staphylococcus aureus ATCC 25923, Aspergillus flavus, and Aspergillus niger were evaluated by Kirby-Bauer disc diffusion and microdilution. Results showed that ethyl acetate extract formed the largest diameter inhibition zone for all tested bacteria and fungi, exhibited antibacterial activity against all tested bacteria with minimum inhibitory concentration (MIC) and minimum bactericidal concentration (MBC) values of 0.39 and $0.78 \mathrm{mg} / \mathrm{mL}$, respectively, and suppressed A. flavus and A. niger with an MIC value of $0.78 \mathrm{mg} / \mathrm{mL}$. This extract contained guaiacol and syringol, which were predicted as the main antimicrobial components in fungus comb. $n$-Hexane extract only inhibited Gram-positive bacteria. S. aureus ATCC 25923 was the most sensitive to all the extracts, and A. flavus was more sensitive than A. niger. All these fungus comb extracts exhibited antimicrobial activity against E. coli ATCC 25922, P. aeruginosa ATCC 27853, S. aureus ATCC 25923, A. flavus, and A. niger. This study revealed that fungus comb extracts, especially ethyl acetate, could be considered as a new antimicrobial agent.
\end{abstract}

\section{Keypoints}

- Ethyl acetate extract from fungus combs exhibited high antimicrobial activity against Staphylococcus aureus ATCC 25923, Escherichia coli ATCC 25922, Pseudomonas aeruginosa ATCC 2785, Aspergillus flavus FNCC 6181, and Aspergillus niger FNCC 6114.

- Ethyl acetate extract from fungus combs contained phenolic compounds such asguaiacol and syringol, which are predicted as the main antimicrobial substances.

\footnotetext{
*Correspondence: dhiantea_k@ugm.ac.id

1 Department of Food and Agricultural Product Technology, Faculty

of Agricultural Technology, Gadjah Mada University, Bulaksumur,

Yogyakarta 55281, Indonesia

Full list of author information is available at the end of the article
} 
- Staphylococcus aureus ATCC 25923 was the most sensitive against $n$-hexane, ethyl acetate, methanol, and water extracts from fungus comb

Keywords: Macrotermes gilvus Hagen, Fungus comb extracts, Antibacterial, Antifungal

\section{Graphical Abstract}

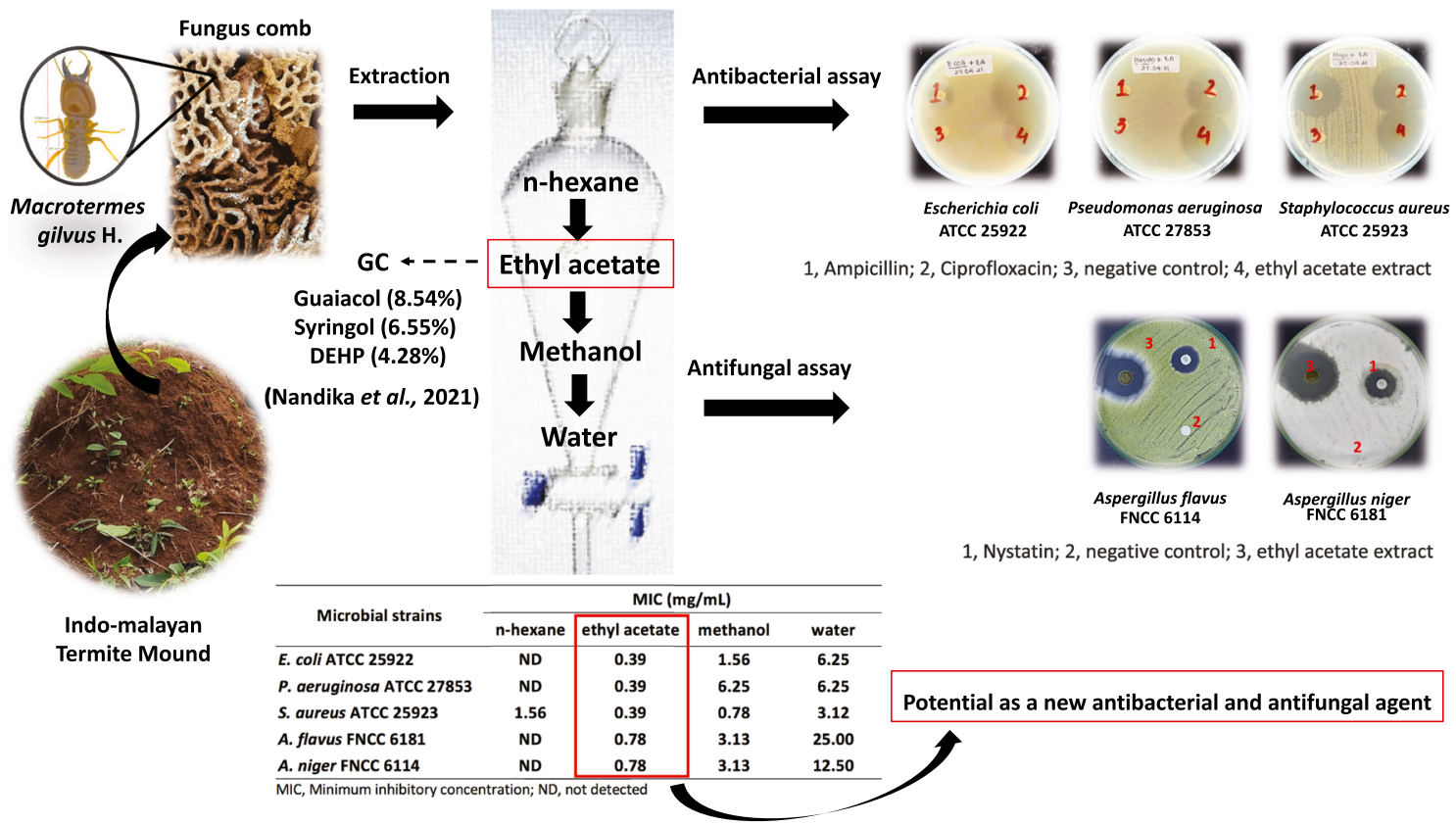

\section{Introduction}

Fruits and vegetables are essential components of a healthy diet; however, produce has recently been associated with diverse foodborne illness outbreaks in many countries. Fruits and vegetables are usually acidic and hence resistant to invasion by bacteria and fungi, especially Aspergillus flavus and Aspergillus niger for corn, tomatoes, grape, strawberries, figs, peaches, pears, apples, citrus, melons, and mangoes (Bui-Klimke and $\mathrm{Wu}$ 2015). A. flavus is a well-recognized producer of aflatoxin, and A. niger is known as ochratoxin producer (Pfliegler et al. 2020). In addition, fresh herbs such as basil, parsley, and leafy greens, especially spinach and lettuce, are potential sources of bacterial contamination (FAO/WHO 2008). Denis et al. (2016) reported bacterial infections from Escherichia coli, Salmonella, and $L$. monocytogenes in retailed fresh vegetables and fruits in Canada. Other pathogenic bacteria that often contaminate food are Staphylococcus aureus and Pseudomonas aeruginosa.

The microbial attack on food products can occur during pre-harvest, transportation, storage, and food processing (Bbosa et al. 2013). In tropical countries, contamination risk during postharvest is higher than in the field due to warm and humid environments. Therefore, maintaining low temperature at $2-3{ }^{\circ} \mathrm{C}$ and relative humidity around $90 \%$ and $95 \%$ is essential to avoid decaycausing fungi (Boer et al. 2009). Although effort has been devoted to adjust the environment, some fruits and vegetables have a high susceptibility to mechanical damage during transportation and a great chance of atmospheric damages due to decreasing oxygen and increasing carbon dioxide levels. According to Feliziani and Romanazzi (2016), consumer request has increased significantly for new technologies of safe and environmentally friendly fruit and vegetable packaging, such as edible or biodegradable coatings. In addition to acting as a barrier to mechanical injury, the coating can be injected by antimicrobial agents that inhibit the growth of food spoilage fungi and bacteria. Therefore, the use of antimicrobial agents in food packaging has become a potential solution for preventing postharvest loss.

Natural products are the most abundant source of antimicrobials. Among which, fungus combs can minimize potentially pathogenic fungi and are competitive in the environment to maintain the health of their colonies (Arango 2015). These special structures are created by termite colonies from the sub-family Macrotermitinae 
(Isoptera: Termitidae) in their nests as a substrate for the growth of only one fungus species, Termitomyces sp. (Arshad and Schnitzer 1987; Arinana et al. 2016). Fungus combs have chemical compounds might suppress the growth of another species and therefore are a potential source of active compounds for an organic antimicrobial agent. Nandika et al. (2021) extracted the chemical components of a fungus comb from Indomalayan termite (Macrotermes gilvus Hagen) (Isoptera: Termitidae) and identified them as phenol, hydroquinone, steroids, terpenoids, and saponin compounds. In addition, the ethyl acetate extract inhibited the growth of Aspergillus foetidus, a fungus that attacks wooden raw materials, including rubberwood (Hevea brasiliensis Muell. Arg.). However, the bioactivity of fungus comb extract from Indomalayan termite ( $M$. gilvus Hagen) mounds as an antifungal and antibacterial agent has not been reported. In the present research, the antifungal and antibacterial activities of fungus comb extracts against A. flavus, A. niger, E. coli ATCC 25922, P. aeruginosa ATCC 27853, and $S$. aureus ATCC 25923 were examined.

\section{Material and methods}

\section{Fungus comb preparation}

Fungus comb extracts were obtained from Indomalayan termite (M. gilvus Hagen) (Isoptera: Termitidae) mounds in Yanlappa Experimental Forest, Bogor, West Java Province by using four different solvents ( $n$-hexane, ethyl acetate, methanol, and water) (Nandika et al. 2021). The extraction yields of $n$-hexane, ethyl acetate, methanol, and water extracts were $0.09 \%, 1.73 \%, 2.53 \%$, and $4.61 \%$, respectively. A sample of $0.5 \mathrm{mg}$ of solid extract was dissolved in $500 \mathrm{~mL}$ of its solvent.

\section{Bacterial culture}

E. coli ATCC 25922, P. aeruginosa ATCC 27853, and S. aureus ATCC 25923 cultures were grown on nutrient agar (OXOID, Basingstoke, England) media, and then incubated at $37^{\circ} \mathrm{C}$ for $18 \mathrm{~h}$. Culture suspensions of E. coli ATCC 25922, S. aureus ATCC 25923, and P. aeruginosa ATCC 27853 were prepared using a physiological solution containing $0.85 \% \mathrm{NaCl}$. The bacterial suspensions were then compared with standard McFarland 0.5 solution $\left(1.5 \times 10^{8} \mathrm{CFU} / \mathrm{mL}\right)$.

\section{Antibacterial susceptibility assay}

Antibacterial susceptibility was detected by disc diffusion in accordance with the standards set by the Clinical Laboratory Standard Institute (CLSI). In brief, $100 \mu \mathrm{L}$ of an overnight culture was diluted in saline solution to $\sim 1.5 \times 10^{8} \mathrm{CFU} / \mathrm{mL}$ (0.5 McFarland turbidity standard). This suspension was flooded into Mueller-Hinton agar (Oxoid Ltd., Basingstoke, UK). The sample's paper disc was dispensed into the inoculated plate and then incubated at $37^{\circ} \mathrm{C}$ for $24 \mathrm{~h}$. The diameters of the clear zones around each paper disc were measured after incubation. Each extract was tested in triplicate.

\section{Determination of minimum inhibitory concentration (MIC) and minimum bactericidal concentration (MBC)}

$\mathrm{MIC}$ and $\mathrm{MBC}$ were determined by microdilution in accordance with CLSI. Each well on the 96-well microplate (BIOLOGIX, Europe) was filled with Mueller-Hinton broth (HiMEDIA, India) media $(100 \mu \mathrm{L})$, suspension of E.coli ATCC 25922, P. aeruginosa ATCC 2785, S. aureus ATCC 25923 (each $10 \mu \mathrm{L}, 1.5 \times 10^{8} \mathrm{CFU} / \mathrm{mL}$ ), and fungus comb extract $(100 \mu \mathrm{L})$. Each well has a different concentration of fungus comb extract, starting from a concentration of $100-0.1 \mathrm{mg} / \mathrm{mL}$. A medium added with bacterial suspension was used as a positive control, and pristine broth medium was used as a negative control. The microplate was incubated at $37^{\circ} \mathrm{C}$ for $18 \mathrm{~h}$, and the MIC values were measured on the basis of turbidity. A turbid solution indicates the presence of bacterial growth. Afterward, the solutions in the microplate were used as samples to determine the MBC value. The samples with different turbidities from clear to turbid were streaked on Mueller-Hinton agar (OXOID, United Kingdom) media and then incubated for $18 \mathrm{~h}$ at $37^{\circ} \mathrm{C}$. The $\mathrm{MBC}$ value was determined as the lowest concentration showing no visible bacterial growth.

\section{Fungal culture}

Strains of A. flavus FNCC 6181 and A. niger FNCC 6114 were grown on potato dextrose agar (MERCK, United States) media, incubated at $30{ }^{\circ} \mathrm{C}$ for $48 \mathrm{~h}$, and stored in the refrigerator. Prior to the assay, the concentration of the culture was adjusted to $10^{6} \mathrm{CFU} / \mathrm{mL}$ counted using a hemocytometer. The culture was resuspended in $1 \mathrm{~mL}$ of $0.05 \%$ Tween 80 .

\section{Antifungal susceptibility assay}

The antifungal activity of fungus comb extracts against A. flavus FNCC 6181 and A. niger FNCC 6114 cultures was examined by Kirby-Bauer disc diffusion using $6 \mathrm{~mm}$ diameter filter paper discs (OXOID, United Kingdom). First, the cultures were diluted in $1000 \mu \mathrm{L}$ of $0.05 \%$ Tween solution to prepare a homogenous single-celled suspension, which was then inoculated by streak/spread method on potato dextrose agar (MERCK, United States) medium using sterile cotton buds. The test was carried out with three extract concentrations: $2.5,25$, and $50 \mathrm{mg} /$ $\mathrm{mL}$. Antifungal susceptibility was determined by measuring the zone of inhibition $(\mathrm{mm})$ after $48 \mathrm{~h}$ of incubation at $30{ }^{\circ} \mathrm{C}$. The samples were compared with an antifungal 


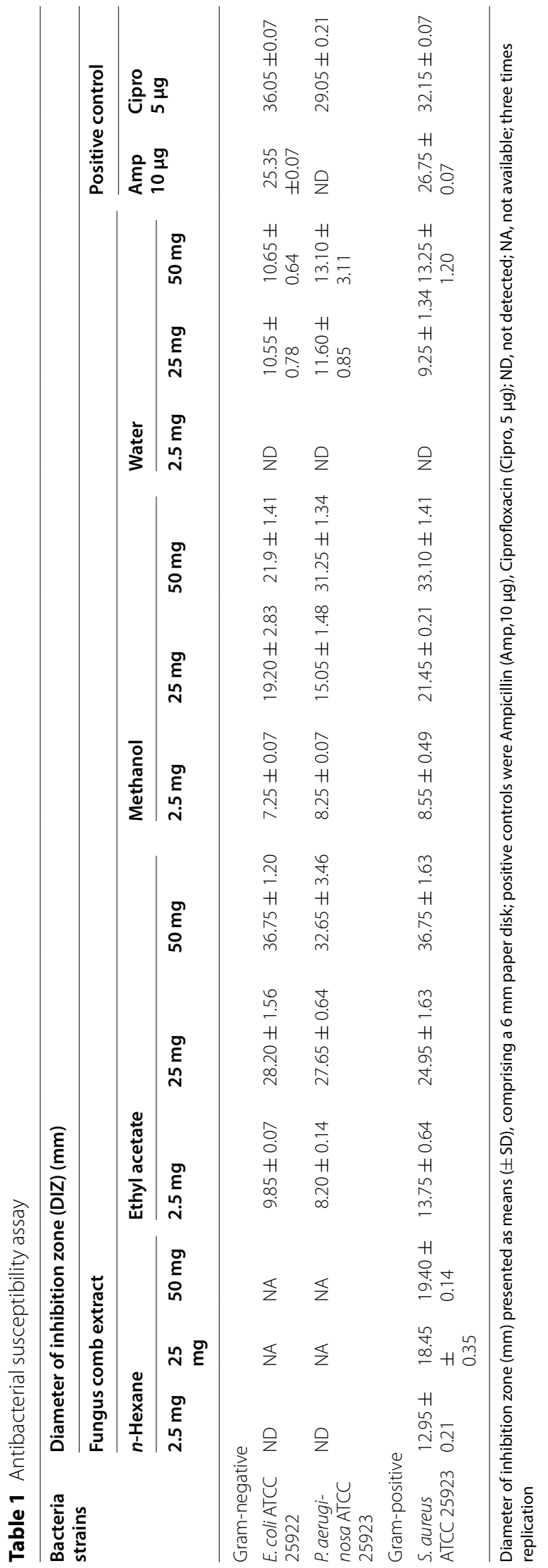


agent, 100 units of nystatin (OXOID, United Kingdom), as a positive control. Each extract was tested in triplicate.

\section{Determination of MIC and minimum fungicidal concentration (MFC)}

MIC was recorded as the lowest concentration of drug permitting the growth of no spores after $48 \mathrm{~h}$ of incubation at $30^{\circ} \mathrm{C}$ for each fungus comb extract determined by its turbidity. Its determination was carried out by microdilution using a Roswell Park Memorial Institute broth medium (GIBCO, United States) with L-glutamine, without sodium bicarbonate $\left(\mathrm{NaHCO}_{3}\right)$ supplemented with $2 \%$ glucose, buffered to $\mathrm{pH} 7.0$ with 4-(2-hydroxyethyl)1-piperazineethanesulfonic acid (HEPES) in a 96-well microplate (BIOLOGIX, Europe). A turbid well indicates the presence of fungal growth and vice versa. Each well was filled with $100 \mu \mathrm{L}$ of broth medium and $100 \mu \mathrm{L}$ of samples, which were then serially twofold diluted to ensure that every well has a different concentration from $100 \mathrm{mg} / \mathrm{mL}$ to $0.1 \mathrm{mg} / \mathrm{mL}$. Afterward, $10 \mu \mathrm{L}$ of suspension of A. flavus FNCC $6181\left(10^{6} \mathrm{CFU} / \mathrm{mL}\right)$ and A. niger FNCC $6114\left(10^{6} \mathrm{CFU} / \mathrm{mL}\right)$. Turbidity was compared with that of the positive control wells containing broth media and fungus culture suspension $\left(10^{6} \mathrm{CFU} / \mathrm{mL}\right)$ and negative control wells containing broth media. The experiment was performed four times. MFC was determined by subculturing the samples from previous MIC value determination. Each well with different turbidities from clear to turbid were streaked on potato dextrose agar medium (MERCK, United States) and then incubated at $30{ }^{\circ} \mathrm{C}$ for $48 \mathrm{~h}$. The assay was performed in triplicate. MFC was recorded as the lowest fungus comb extract concentration showing no visible growth of $A$. flavus FNCC 6181 and $A$. niger FNCC 6114.

\section{Results}

\section{Antibacterial activity}

The antibacterial susceptibility of fungus comb extracts against Gram-negative (E. coli ATCC 25922 and P. aeruginosa ATCC 2785) and Gram-positive (S. aureus ATCC 25923) bacteria was examined by Kirby-Bauer agar diffusion. The diameter inhibition zones (DIZs) resulting from exposure to $n$-hexane, ethyl acetate, methanol, and water extracts of fungus comb are shown in Table 1. The clear zones on bacteria tested with fungus comb extracts are presented in Fig. 1.

A high dosage of extracts resulted in a large DIZ in all tested bacteria. Ethyl acetate extract formed the largest DIZ against all tested bacteria. S. aureus ATCC 25923 was the most sensitive to all the extracts. Owing to the limitation of $n$-hexane extract, the DIZ data of high doses are unavailable for E. coli ATCC 25922 and P. aeruginosa ATCC 2785. Nevertheless, this extract in the lowest dose inhibited S. aureus ATCC 25923 but no other bacteria (Fig. 1c). Ampicillin and ciprofloxacin were used as the positive control. Ciprofloxacin in a lower dosage than the fungus comb extracts showed strong inhibition against all tested bacteria. Ampicillin inhibited only E. coli ATCC 25922 and S. aureus (Table 1).

Ethyl acetate extract showed the lowest MIC of $0.39 \mathrm{mg} / \mathrm{mL}$ and $\mathrm{MBC}$ of $0.78 \mathrm{mg} / \mathrm{mL}$ in all tested bacteria. $n$-Hexane extract had MIC of $1.56 \mathrm{mg} / \mathrm{mL}$ and $\mathrm{MBC}$ of $3.13 \mathrm{mg} / \mathrm{mL}$ only for Gram-positive bacteria (Table 2, Additional file 1: Figure S1, Figure S2).

\section{Antifungal activity}

The antifungal activity of fungus comb extracts against A. flavus FNCC 6181 and A. niger FNCC 6114 as determined by the clear zone diameter $(\mathrm{mm})$ was examined by Kirby-Bauer disc diffusion (Table 3 and Fig. 2). Ethyl acetate extract generated the largest DIZ against $A$. flavus FNCC 6181 and A. niger FNCC 6114 (Table 3). Methanol and water extracts also inhibited both fungi at high dosages ( 25 and $50 \mathrm{mg}$ ). Unfortunately, both fungi were resistant to $n$-hexane extract. Nystatin at $100 \mathrm{U}$ dosage was used as the positive control.

The results of MIC and MFC investigation supported those from the antifungal susceptibility assay. The lowest MIC and MFC values against A. flavus FNCC 6181 and $A$. niger FNCC 6114 were observed for ethyl acetate extract. The MIC and MFC values for both fungi were not detected for $n$-hexane extract (Table 4, Additional file 1: Figure S3, Figure S4).

\section{Discussion}

This study reported the bioactivity of fungus comb extracts from Indomalayan termite ( $M$. gilvus $\mathrm{H}$.) mounds as an antifungal and antibacterial agent against food spoilage microorganisms. The antibacterial activity of fungus comb extracts was tested against $E$. coli ATCC 25922, P. aeruginosa ATCC 27853, and S. aureus ATCC 25923, and their antifungal activity was examined against A. flavus FNCC 6181 and A. niger FNCC 6114.

The bacterial inhibitory action of fungus comb extracts differs considerably among species. Ethyl acetate extract generated the largest DIZ against the tested Gram-positive and -negative bacteria, followed by methanol and water extracts (Table 1 and Fig. 1). Water extract inhibited all tested bacteria at a high dosage but not at its lowest dosage. S. aureus ATCC 25923 was the most sensitive to all the extracts. $n$-Hexane extract inhibited only Grampositive bacteria, which are generally more sensitive than Gram-negative bacteria due to their lack of outer membrane (lipopolysaccharide and lipoprotein). In addition, their cell wall architecture tolerates hydrophobic 


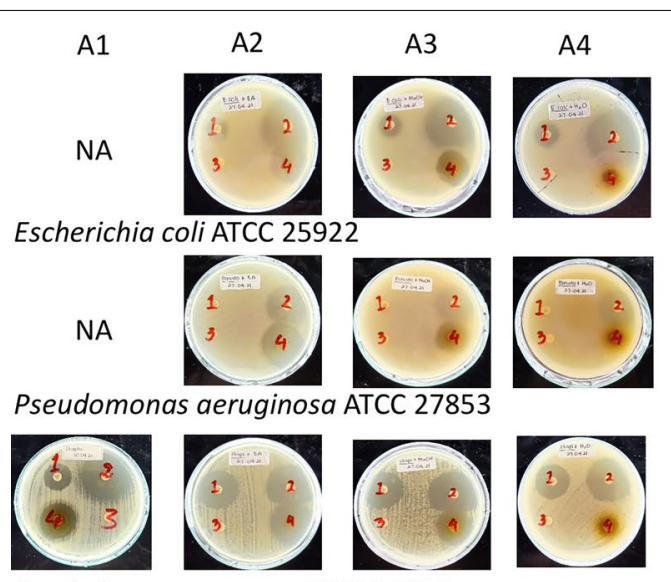

Staphylococcus aureus ATCC 25923

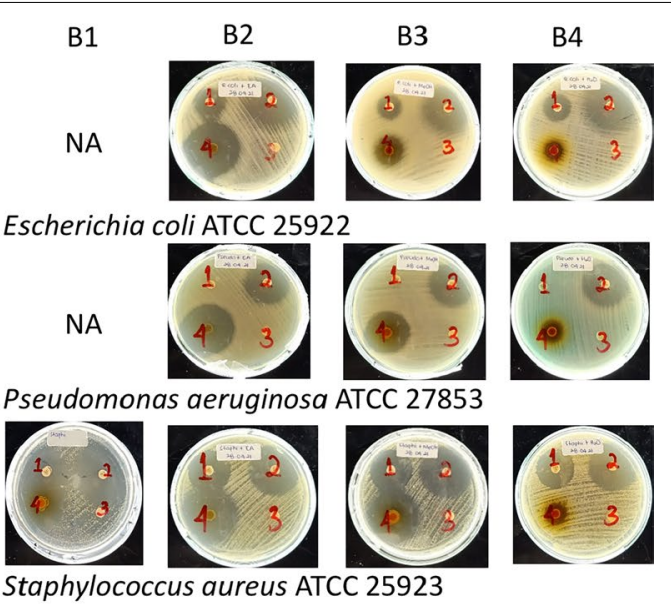

a

b

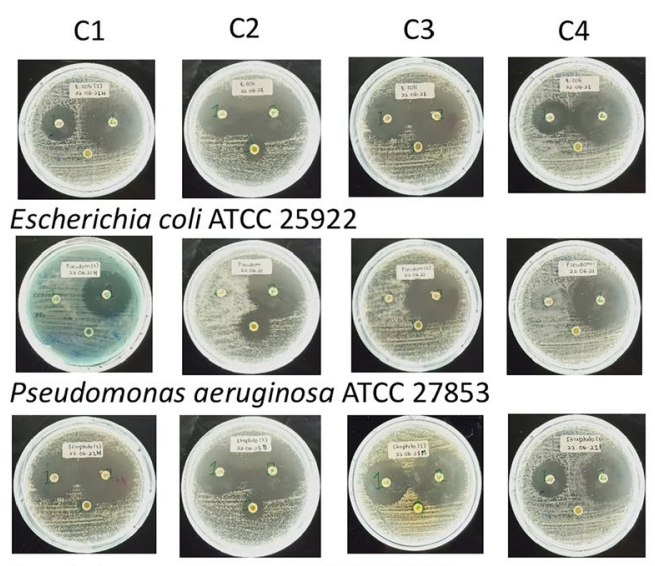

Staphylococcus aureus ATCC 25923

\section{C}

Fig. 1 Inhibitory activity of fungus comb extract against E. coli ATCC 25922, P. aeruginosa ATCC 27853 and S. aureus ATCC 25923. A1, B1, C1, n-hexane extract; A2, B2, C2, ethyl acetate extract; A3, B3, C3, methanol extract; A4, B4,C4, water extract. a 50 mg; b 25 mg; c 2.5 mg; 1, Ampicillin 10 g; 2 , Ciprofloxacin $5 \mu \mathrm{g} ; 3$, negative control (solvent); 4 , fungus comb extracts

Table 2 MIC and MFC value of fungus comb extract against bacterial strains

\begin{tabular}{|c|c|c|c|c|c|c|c|c|}
\hline \multirow[t]{3}{*}{ Bacteria strains } & \multicolumn{8}{|c|}{ Fungus comb extract } \\
\hline & \multicolumn{2}{|l|}{$n$-Hexane } & \multicolumn{2}{|l|}{ Ethyl acetate } & \multicolumn{2}{|l|}{ Methanol } & \multicolumn{2}{|l|}{ Water } \\
\hline & $\mathrm{MIC}(\mathrm{mg} / \mathrm{mL})$ & $\mathrm{MBC}(\mathrm{mg} / \mathrm{mL})$ & $\mathrm{MIC}(\mathrm{mg} / \mathrm{mL})$ & $\mathrm{MBC}(\mathrm{mg} / \mathrm{mL})$ & $\mathrm{MIC}(\mathrm{mg} / \mathrm{mL})$ & $\mathrm{MBC}(\mathrm{mg} / \mathrm{mL})$ & $\mathrm{MIC}(\mathrm{mg} / \mathrm{mL})$ & $\mathrm{MBC}(\mathrm{mg} / \mathrm{mL})$ \\
\hline \multicolumn{9}{|c|}{ Gram negative bacteria } \\
\hline E.coli ATCC 25922 & ND & ND & $0.39 \pm 0$ & $0.78 \pm 0$ & $1.56 \pm 0$ & $3.13 \pm 0$ & $6.25 \pm 0$ & $12.5 \pm 0$ \\
\hline $\begin{array}{l}\text { P. aeruginosa ATCC } \\
27853\end{array}$ & ND & ND & $0.39 \pm 0$ & $0.78 \pm 0$ & $6.25 \pm 0$ & $12.5 \pm 0$ & $6.25 \pm 0$ & $12.5 \pm 0$ \\
\hline \multicolumn{9}{|c|}{ Gram positive bacteria } \\
\hline $\begin{array}{l}\text { S. aureus ATCC } \\
25923\end{array}$ & $1.56 \pm 0$ & $3.13 \pm 0$ & $0.39 \pm 0$ & $0.78 \pm 0$ & $0.78 \pm 0$ & $1.56 \pm 0$ & $3.13 \pm 0$ & $6.25 \pm 0$ \\
\hline
\end{tabular}




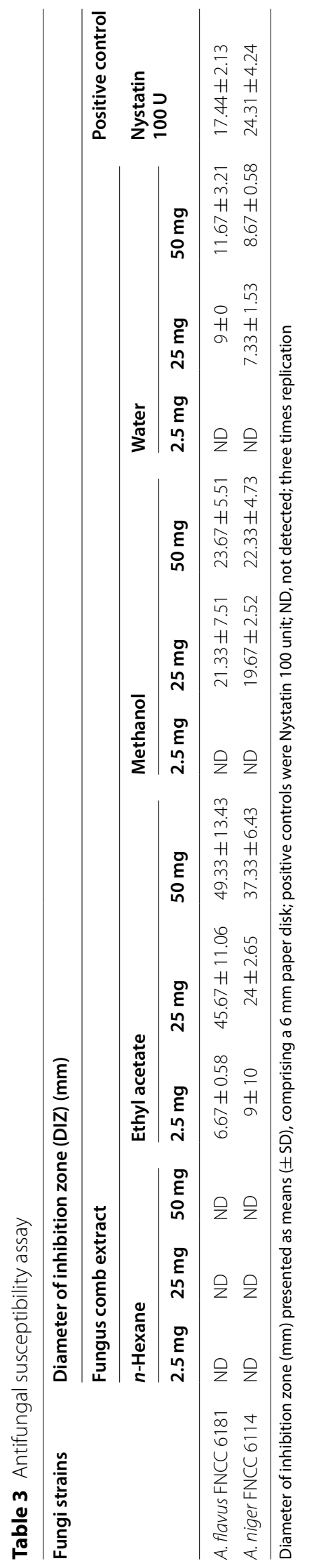




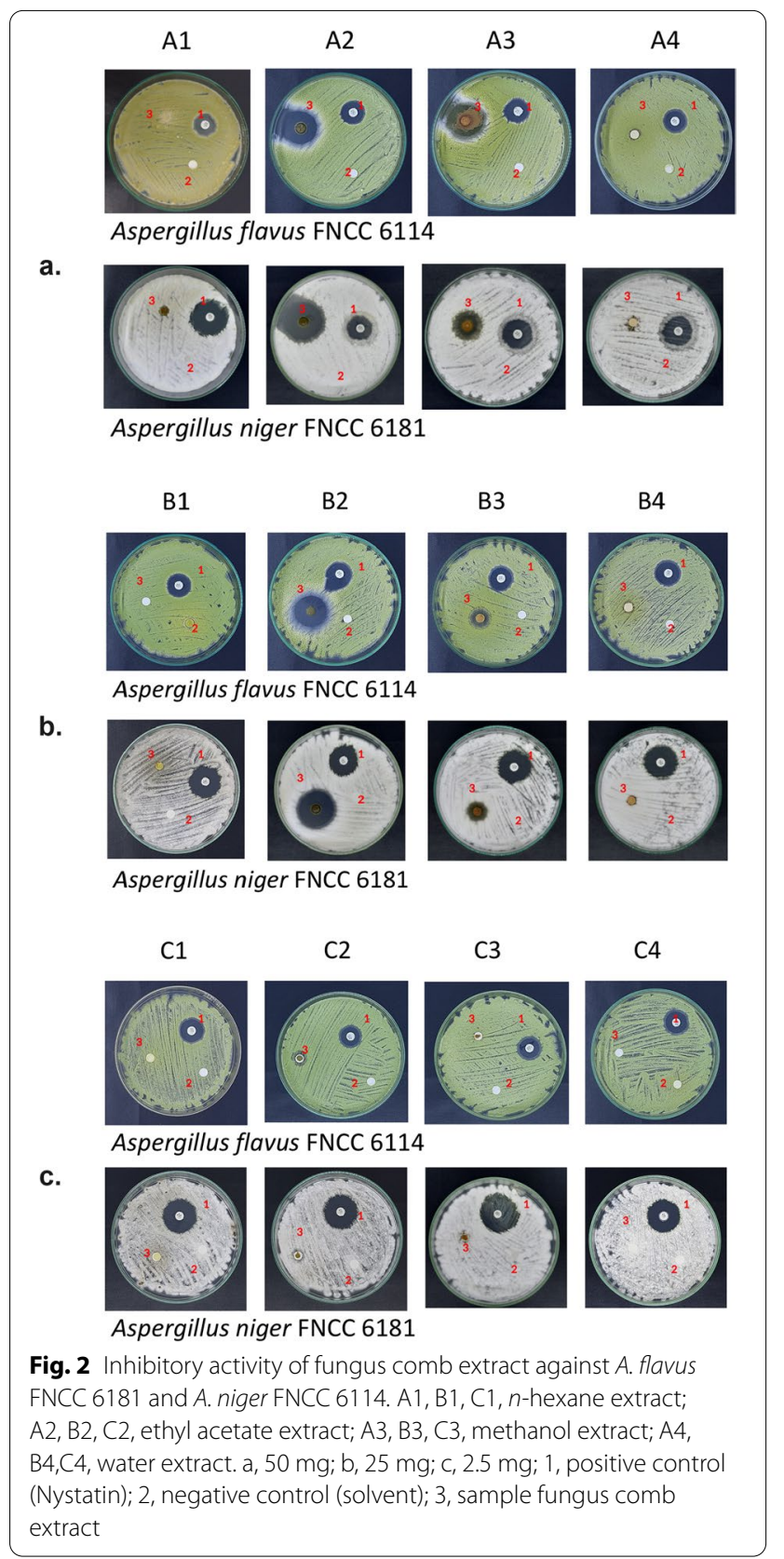

molecules and allows them to easily permeate into the cells (Nazzaro et al. 2013).

Microdilution was used to determine MIC (the smallest concentration of antimicrobials to inhibit microorganism growth) and $\mathrm{MBC}$ (the smallest concentration that can inhibit microorganism growth and kill microbes characterized by the absence of colonies on agar media after scraping from each microplate well after incubation) (Migliato et al. 2010). The results showed that ethyl acetate extract exhibited significant antibacterial activity against E. coli ATCC 25922, P. aeruginosa ATCC 2785), and S. aureus ATCC 25923 with MIC and MBC values of 0.39 and $0.78 \mathrm{mg} / \mathrm{mL}$, respectively (Table 2, Additional file 1: Figures S1, S2).

Comparable with antifungal agents such as nystatin, fungus comb extracts showed positive inhibition (Table 3 and Fig. 2). The highest antifungal activity was observed from ethyl acetate extract, followed by methanol. Water extract showed the lowest antifungal activity, and $n$-hexane extract did not inhibit $A$. flavus FNCC 6181 nor $A$. niger FNCC 6114 . The largest DIZ was generated by ethyl acetate at $50 \mathrm{mg}$ of dosage against $A$. flavus FNCC 6181. These results showed that A. flavus FNCC 6181 was more sensitive than $A$. niger FNCC 6114 (Table 3). The lowest MIC and MFC values were observed for ethyl acetate extract against $A$. flavus FNCC 6181 and $A$. niger FNCC 6114 (Table 4).

The chemical composition of ethyl acetate extract from fungus combs was previously analyzed by gas chromatography (Nandika 2021) (Additional file 1: Figure S5, Table S1). The dominant compounds were glycerol (28.93\%), phenol, 2-methoxy- (8.54\%), phenol, 2,6-dimethoxy- (6.55\%), and bis(2-ethylhexyl) phthalate (DEHP) (4.28\%). Meanwhile, the as major compounds of $n$-hexane extract consisted of DEHP (69.43\%), methyl palmitate $(4.55 \%)$, methyl oleate $(4.17 \%)$, methyl linolelaidate (2.03\%) and benzenepropanoic acid, 3,5-bis $(1,1$ dimethylethyl)-4-hydroxy-,methyl ester (1.16\%) (Additional file 1: Figure S5, Table S2).

Among these compounds, DEHP is an ester of phthalic acid and naturally synthesized by plants or microorganisms such as fungi and bacteria with different biological activities (Ortiz and Sansinenea 2018). DEHP isolated

Table 4 MIC and MFC value of fungus comb extract against fungi strains

\begin{tabular}{|c|c|c|c|c|c|c|c|c|}
\hline \multirow[t]{3}{*}{ Fungi strains } & \multicolumn{8}{|c|}{ Fungus comb extract } \\
\hline & \multicolumn{2}{|l|}{ n-Hexane } & \multicolumn{2}{|l|}{ Ethyl acetate } & \multicolumn{2}{|l|}{ Methanol } & \multicolumn{2}{|l|}{ Water } \\
\hline & $\mathrm{MIC}(\mathrm{mg} / \mathrm{mL})$ & MFC (mg/mL) & $\mathrm{MIC}(\mathrm{mg} / \mathrm{mL})$ & $\mathrm{MFC}(\mathrm{mg} / \mathrm{mL})$ & $\mathrm{MIC}(\mathrm{mg} / \mathrm{mL})$ & $\mathrm{MFC}(\mathrm{mg} / \mathrm{mL})$ & $\mathrm{MIC}(\mathrm{mg} / \mathrm{mL})$ & $\mathrm{MFC}(\mathrm{mg} / \mathrm{mL})$ \\
\hline A. flavus FNCC 6181 & ND & ND & $0.78 \pm 0$ & $1.56 \pm 0$ & $3.13 \pm 0$ & $6.25 \pm 0$ & $25 \pm 0$ & $25 \pm 0$ \\
\hline A. niger FNCC 6114 & ND & ND & $0.78 \pm 0$ & $1.56 \pm 0$ & $3.13 \pm 0$ & $3.13 \pm 0$ & $12.50 \pm 0$ & $12.50 \pm 0$ \\
\hline
\end{tabular}

ND, not detected, three times replication 
from Calotropis gigantea plant exhibits antimicrobial activity against E. coli, S. aureus, Bacillus subtilis, Shigella dysenteriae Shigella shiga, Shigella sonnei, Sarcina lutea, and A. flavus (Habib and Karim 2009). Fungi can produce this compound. DEHP was recently isolated from Aspergillus awamori and displayed antifungal and antibacterial activities against Candida albicans and Gram-positive bacteria Sarcina lutea (Lotfy et al. 2018). Aspergillus fumigatus also secrete DEHP (Abdel-Aziz et al. 2018). Penicillium janthinellum contains DEHP as a major bioactive compound with antioxidant, antitumor, and antiviral activities (El-Sayed et al. 2015). Actinomycetes (filamentous bacteria) can generate this compound. DEHP isolated from Streptomyces sp. TN17 showed antimicrobial activities against Gram-positive bacteria and fungi (Smaoui et al. 2011). Nocardia levis secretes DEHP that inhibits Gram-positive bacteria and fungi (Kavitha et al. 2009). DEHP is the major component of $n$-hexane extract from fungus combs. Therefore, termites (M. gilvus $\mathrm{H}$.) might synthesize DEHP to suppress the growth of another species. $n$-Hexane extract inhibited only Grampositive bacteria with MIC of $1.56 \mathrm{mg} / \mathrm{mL}$ and $\mathrm{MBC}$ of $3.13 \mathrm{mg} / \mathrm{mL}$ but not fungus Aspergillus. Therefore, another compound in fungus comb is responsible for its antifungal activity.

Phenolic compounds are extensively available in plant tissues and have a critical role in highly effective bioactivity. Phenol is a well-known antibacterial agent, i.e., 2-methoxyphenol (guaiacol) and 2,6-dimethoxyphenol (syringol). Guaiacol and syringol isolated from C. japonica wood vinegar showed a strong antimicrobial effect against Pythium splendens, Ralstonia solanacearum, Fusarium oxysporum, and Phytophthora capsici. Guaiacol had MIC values of $1.25 \mathrm{mg} / \mathrm{mL}$ against $R$. solanacearum and P. splendens and $2.5 \mathrm{mg} /$ $\mathrm{mL}$ against $P$. capsica and $F$. oxysporum (Hwang et al. 2005). Another study showed the antibacterial activity of Litchi chinensis wood vinegar against S. aureus, Acinetobacter baumannii, and $P$. aeruginosa due to its high phenolic compositions such as 2,6-dimethoxyphenol (29.54\%), 2-methoxyphenol (12.36\%), and 3,5-dimethoxy-4-hydroxytoluene (11.07\%) (Yang et al. 2016). Ethyl acetate extract from fungus combs also consisted of guaiacol, syringol, and DEHP and exhibited antibacterial and antifungal activities against $S$. aureus ATCC 25923, E. coli ATCC 25922, P. aeruginosa ATCC 2785, A. flavus FNCC 6181, and A. niger FNCC 6114. Given their presence in ethyl acetate extract from fungus combs at relatively high concentrations, both phenols were regarded as the major antimicrobial constituents in fungus comb. Furthermore, guaiacol and syringol are generally recognized as safe by the Flavor Extract Manufacturers Association. According to Joint FAO/WHO
Expert Committee on Food Additives, these compounds are safe for food application. Therefore, ethyl acetate extract from fungus combs shows potential use for food preservation, such as in food packaging. Its application as an antimicrobial agent in packaging material must be further investigated.

\section{Abbreviations}

E. coli: Escherichia coli; P. aeruginosa: Pseudomonas aeruginosa; S. aureus: Staphylococcus aureus; A. flavus: Aspergillus flavus; A. niger: Aspergillus niger; MIC: Minimum inhibitory concentration; MBC: Minimum bactericidal concentration; MFC: Minimum Fungicidal Concentration; DIZ: Diameter Inhibition Zone; Amp: Ampicillin; Cipro: Ciprofloxacin; DEHP: Bis(2-ethylhexyl) phthalate; Guaiacol: 2-Methoxy-phenol; Syringol: 2:6-Dimethoxyphenol; ND: Not detected; NA: Not available.

\section{Supplementary Information}

The online version contains supplementary material available at https://doi. org/10.1186/s13568-022-01359-0.

Additional file 1: Figure S1. MIC of fungus comb extracts against Escherichia coli ATCC 25922, Staphylococcus aureus ATCC 25923 and Pseudomonas aeruginosa ATCC 27853. Figure S2. MBC of fungus comb extracts against Escherichia coli ATCC 25922, Staphylococcus aureus ATCC 25923 and Pseudomonas aeruginosa ATCC 27853. Figure S3. MIC of fungus comb extracts against Aspergillus flavus FNCC 6181 and Aspergillus niger FNCC 6114. Figure S4. MFC of fungus comb extracts against Aspergillus flavus FNCC 6181 and Aspergillus niger FNCC 6114. Figure S5. Chromatogram of GCMS analysis of the ethyl acetate (a) n-hexane (b) extracts. Table S1. The chemical composition of fungus comb ethyl acetate extract. Table S2. The chemical composition of fungus comb n-hexane extract.

\section{Acknowledgements}

We are grateful to Anang Juni Yustanto and Th. Novi Dwinawati for their technical assistance in the laboratory.

\section{Authors' contributions}

LDW and DN conceived and designed research. KWW, BJA, DCK and IB conducted experiments. Sample collection by AA, LK, DN. LDW, KWW, BJA, DCK and IB analyzed data. LDW, KWW, BJA and DCK wrote the manuscript. AH, LK, $A A, I B, D S, Y R, D F$, IKS and DMH revised the manuscript. All authors read and approved the manuscript.

\section{Funding}

This study was supported by Gajah Mada University, IPB University, Institut Teknologi Bandung, and Airlangga University, Indonesia, under the Indonesian Collaborative Research Scheme FY 2021 (contract No. 810/UN1.DITLIT/DIT-LIT/ PT/2021).

\section{Availability of data and materials}

The authors declare that data supporting the findings of this study are available within the article and its supplementary information files.

\section{Declarations}

Ethics approval and consent to participate

This article does not contain any studies with human or animal participants performed by any of the authors.

Consent for publication

All authors consent to the publication of this manuscript.

Competing interests

The authors declare that no competing interests. 


\section{Author details}

${ }^{1}$ Department of Food and Agricultural Product Technology, Faculty of Agricultural Technology, Gadjah Mada University, Bulaksumur, Yogyakarta 55281, Indonesia. ${ }^{2}$ Faculty of Veterinary Medicine, Gadjah Mada University, Bulaksumur, Yogyakarta 55281, Indonesia. ${ }^{3}$ Department of Forest Products, Faculty of Forestry and Environment, IPB University, Darmaga Campus, Bogor 16680, West Java, Indonesia. ${ }^{4}$ Department of Chemistry, Faculty of Mathematics and Natural Sciences, Tropical Biopharmaca Research Center, IPB University, Darmaga Campus, Bogor 16680, West Java, Indonesia. ${ }^{5}$ Faculty of Medicine, Campus A Universitas Airlangga, Surabaya 60132, East Java, Indonesia. ${ }^{6}$ Department of Chemistry, Faculty of Mathematics and Natural Sciences, Institut Teknologi Bandung, Bandung 40132, West Java, Indonesia.

Received: 10 December 2021 Accepted: 1 February 2022

Published online: 10 February 2022

\section{References}

Abdel-Aziz MS, Ghareeb MA, Saad AM, Refahy LA, Hamed AA (2018) Chromatographic isolation and structural elucidation of secondary metabolites from the soil-inhabiting fungus Aspergillus fumigatus 3T-EGY. Acta Chromatogr 30(4):243-249. https://doi.org/10.1556/1326.2017.00329

Arango RA (2015) First record of the arid-land termite, reticulitermes tibialis Banks, in Wisconsin. Gr Lakes Entomol 47:211-212

Arinana A, Aldina R, Nandika D, Rauf A, Harahap IS, Sumertajaya IM, Bahtiar ET (2016) Termite diversity in urban landscape, South Jakarta Indonesia. Insects 7(2):20. https://doi.org/10.3390/insects7020020

Arshad MA, Schnitzer M (1987) The chemistry of a termite fungus comb. Plant Soil 98:247-256

Bbosa GS, Kitya D, Lubega A, Ogwal-Okeng J, Anokbonggo WW, Kyegombe DB (2013) Review of the biological and health effects of aflatoxins on body organs and body systems. Aflatoxins-recent advances and future prospects. Intech Open Access, London, pp 239-265

Boer SHJ, Boyd-Wilson KSH, Petley M, Walter M (2009) Influence of cold-storage temperatures on strawberry leak caused by Rhizopus spp. NZ Plant Prot 62:243-249. https://doi.org/10.30843/nzpp.2009.62.4827

Bui-Klimke TR, Wu F (2015) Ochratoxin A and human health risk: a review of the evidence. Crit Rev Food Sci Nutr. https://doi.org/10.1080/10408398. 2012.724480

Denis N, Zhang H, Leroux A, Trudel R, Bietlot H (2016) Prevalence and trends of bacterial contamination in fresh fruits and vegetables sold at retail in Canada. Food Control 67:225-234. https://doi.org/10.1016/j.foodcont. 2016.02.047

El-Sayed OH, Asker MMS, Shash SM, Hamed SR (2015) Isolation, structure elucidation and biological activity of di-(2-ethylhexyl) phthalate produced by Penicillium janthinellum. Int J Chem Tech Res 8(1):58-66

FAO/WHO (2008) Microbiological risk assessment series 14: Microbiological hazards in fresh leafy vegetables and herbs. Retrieved from ftp://ftp.fao. org/docrep/fao/011/i0452e/i0452e00.pdf. Accessed 18 Nov 2021

Feliziani E, Romanazzi G (2016) Postharvest decay of strawberry fruit: etiology, epidemiology, and disease management. J Berry Res 6(1):47-63. https:// doi.org/10.3233/JBR-150113

Habib MR, Karim MR (2009) Antimicrobial and cytotoxic activity of di-(2-ethylhexyl) phthalate and anhydrosophoradiol-3-acetate isolated from Calotropis gigantea (Linn.) flower. Mycobiology. https://doi.org/10.4489/ MYCO.2009.37.1.031

Hwang Y-H, Matsushita Y, Sugamoto K, Matsui T (2005) Antimicrobial effect of the wood vinegar from Cryptomeria japonica sapwood on plant pathogenic microorganisms. J Microbiol Biotechnol 15(5):1106-1109

Kavitha A, Prabhakar P, Vijayalakshmi M, Venkateswarlu Y (2009) Production of bioactive metabolites by Nocardia levis MK-VL_113. Lett Appl Microbiol 49(4):484-490. https://doi.org/10.1111/j.1472-765X.2009.02697.x

Lotfy MM, Hassan HM, Hetta MH, El-Gendy AO, Mohammed R (2018) Di(2-ethylhexyl) phthalate, a major bioactive metabolite with antimicrobial and cytotoxic activity isolated from River Nile derived fungus Aspergillus awamori. Beni Suef Univ J Basic Appl Sci 7(3):263-269. https://doi.org/10. 1016/j.bjbas.2018.02.002

Migliato KF, Mello J, Higa O, Rodas A, Correa MA, Mendes-Giannini MJ, FuscoAlmeida A, Pizzolitto AC, Salgado HR (2010) Antimicrobial and cytotoxic activity of fruit extract from Syzygium cumini (L) Skeels. Lat Am J Pharm 29(5):725-730. https://doi.org/10.33448/RSD-V1012.12272

Nandika D, Karlinasari L, Arinana A, Batubara I, Sitanggang PS, Witasari SD, LD, Rachmayanti Y, Firmansyah D, Sudiana IK, Hertanto DM, (2021) Chemical components of fungus comb from Indo-Malayan termite Macrotermes gilvus hagen mound and its bioactivity against wood-staining fungi. Forests 12:1591. https://doi.org/10.3390/f12111591

Nazzaro F, Fratianni F, De Martino L, Coppola R, De Feo V (2013) Effect of essential oils on pathogenic bacteria. Pharmaceuticals 6:1451-1474. https:// doi.org/10.3390/ph6121451

Ortiz A, Sansinenea E (2018) Di-2-ethylhexylphthalate may be a natural product, rather than a pollutant. J Chem. https://doi.org/10.1155/2018/ 6040814

Pfliegler WP, Pócsi I, Györi Z, Pusztahelyi T (2020) The Aspergilli and their mycotoxins: metabolic interactions with plants and the soil biota. Front Microbiol. https://doi.org/10.3389/fmicb.2019.02921

Smaoui S, Mellouli L, Lebrihi A, Coppel Y, Fguira LFB, Mathieu F (2011) Purification and structure elucidation of three naturally bioactive molecules from the new terrestrial Streptomyces sp. TN17 strain. Nat Prod Res 25(8):806814. https://doi.org/10.1080/14786410902986225

Yang J, Yang C, Liang M, Gao Z, Wu Y, Chuang L (2016) Chemical composition, antioxidant, and antibacterial activity of wood vinegar from Litchichinensis. Molecules 21(9):1150. https://doi.org/10.3390/molecules21091150

\section{Publisher's Note}

Springer Nature remains neutral with regard to jurisdictional claims in published maps and institutional affiliations.

\section{Submit your manuscript to a SpringerOpen ${ }^{\circ}$ journal and benefit from:}

- Convenient online submission

- Rigorous peer review

- Open access: articles freely available online

- High visibility within the field

- Retaining the copyright to your article

Submit your next manuscript at $\boldsymbol{\nabla}$ springeropen.com 